\title{
Circular economy enabled by additive manufacturing: potential opportunities and key sustainability aspects
}

\author{
Mariia Kravchenko ${ }^{1}$, Daniela C.A. Pigosso ${ }^{1}$, Tim C. McAloone ${ }^{1}$ \\ ${ }^{1}$ Technical University of Denmark \\ makrav@dtu.dk,danpi@dtu.dk,tmca@dtu.dk
}

\begin{abstract}
Additive manufacturing is arguably a cornerstone of the new digital manufacturing, Industry 4.0, which holds enormous opportunities to increase operational and customer effectiveness. Additive manufacturing is also seen as a powerful enabler of circular economy (CE), which aims at reducing resource consumption while boosting business opportunities. No waste production and reduced physical inventories are just few examples of how AM could positively contribute to CE goal. This paper aims at, firstly, exploring what CE strategies can be enabled by AM, and secondly, providing examples of key sustainability aspects to be considered in early design of AM-enabled CE strategies. Our findings show that AM has a great potential in supporting a variety of $\mathrm{CE}$ strategies, ranging from providing recycled materials, to original manufacturing, repair and remanufacturing activities, to recycling of materials at the end of life. Furthermore, AM could play a key role in helping businesses to transform their business models and design new products. Using a database of sustainability indicators, we provide examples of key sustainability aspects to consider when planning an AM-enabled CE strategy. Consideration of sustainability aspects is important in the planning and design stage, in order to understand and subsequently measure potential contribution to sustainability. With few examples we show that there are is a need to make a case by case analysis as there is no universally best AM-enabled technology sustainability wise.
\end{abstract}

Keywords: circular economy, additive manufacturing, sustainability aspects, planning and design

\section{Introduction}

Manufacturing plays a vital role for the EU economy, providing millions of jobs and contributing to roughly $20 \%$ of the region's GDP, while approaching $50 \%$, when taking into account related services that either offered by or depend on the industry, the so called ,servoindustrial economy“ (EC, 2019). While driving the economic growth within EU, industry has shown a striking increase in manufacturing productivity, which has led to labour optimization, resource efficiency and cost reduction. Improved productivity and resource use performance can be attributed to several important factors such as process and product innovation, outsourcing and digitalization (Antikainen, Uusitalo, \& Kivikytö-Reponen, 2018; EC, 2019). Increasing use of digital technologies are providing novel ways to design, deliver and monitor 
products to satisfy consumer needs, to plan and control production and analyse usage and trends to increase in-use operational effectiveness. Digital technologies have triggered appearance of other, more disruptive technologies, such as artificial intelligence (AI), blockchain, robotics, additive manufacturing (AM or 3D printing (3DP)), which have been described as radical technologies to fundamentally transform manufacturing into new, digital, industrial system Industry 4.0 (KPMG International \& International, 2016; Ogden, 2018). Particularly, AM has attracted attention as a 'game-changer' for conventional manufacturing regarding opportunities for mass customization, local (distributed) production, no-waste printing process, spare part printing for repair and remanufacturing (Despeisse et al., 2017; Matsumoto et al., 2016). Because of these inherent features, industry and researchers are raising expectations towards AM beneficial contribution to circular economy (CE) (Despeisse et al., 2017; Zhong \& Pearce, 2018), which aims at keeping value of resources by prolonging product life, efficient and effective use of resources and elimination of waste, all facilitated by technological and socioinstitutional change. Furthermore, AM is seen as an enabler of sustainability, which can be achieved through adoption of CE principles (Angioletti, Sisca, Luglietti, Taisch, \& Rocca, 2016). Despite the evident link between AM and CE principles, neither CE strategies nor AM are sustainable by-default, which calls for their design, planning and assessment considering a variety of sustainability issues (Korhonen, Honkasalo, \& Seppälä, 2018).

With this paper, we aim to investigate how AM can enable CE. To achieve this, we provide review of the extant literature to understand what $\mathrm{CE}$ strategies can be supported by AM. Subsequently, we provide examples of significant sustainability aspects to be considered by industrial practitioners to support more informed planning and design of AM-enabled CE. We focus on key environmental, economic and social aspects based on 'target' CE strategy.

\section{Background}

\subsection{Additive manufacturing}

According to ASTM, the technical committee responsible for the development of additive manufacturing standards, AM is "a process of joining materials to make objects from 3D model data, usually layer upon layer, as opposed to subtractive manufacturing methodologies" (Matsumoto et al., 2016). In essence, a 3D model of an object is designed digitally, then sent to a printing machine, which needs energy (electricity, heat) and AM suitable materials to produce a physical object, which then, in most cases, would require finishing (post-processing) to smoothen rough surface (e.g. polishing) (Matsumoto et al., 2016). Aerospace, automotive, medical and healthcare industries have already been utilizing AM for product development and spare part manufacturing (Dansk AM Hub, 2020; Kellens et al., 2017). Among the most common materials used in AM are (Kellens et al., 2017; Shahrubudin, Lee, \& Ramlan, 2019):

- Metals: aluminium alloys, cobalt-based alloys, nickel-based alloys, stainless steels, and titanium alloys, silver, gold;

- Polymers: polylactic acid (PLA), acrylonitrile butadiene styrene (ABS), polypropylene (PP) or polyethylene (PE);

- Ceramics: alumina, bioactive glasses and zirconia;

- Composites: fiberglass

In addition, some special materials are being used such as nickel-titanium (so called 'smart material' due to its ability of shape-memory, i.e. to alter the geometry and shape of object) and food materials, such as chocolate and pasta. Such variety of materials makes it possible to consider AM by many more industries such as fashion, construction, furniture and food.

In relation to large scale professional manufacturing, AM can be classified into seven main types of AM processes, which can then be subdivided into 18 technologies depending on the 
type of input they require (Arrizubieta, Ukar, Ostolaza, \& Mugica, 2020; Matsumoto et al., 2016). For instance, there exists liquid-based, powder-based and solid-based processes: binder jetting (BJ) is a liquid-based process, where liquid printing binder is deployed onto specific coordinate that sticks at the particle until it becomes a 3D object (Arrizubieta et al., 2020); direct energy deposition (DED) is a powder-based process, using a focused thermal energy beam to melt and fuse (powder) materials (often metals in powder form) (Matsumoto et al., 2016); fused deposition modelling (FDM) is a solid-based process, where heated materials precipitate through a heated nozzle (e.g. polymers) (Rahito, Wahab, \& Azman, 2019). Sometimes AM machines do not require special set-ups using jigs and fixtures, which allows a more speedy work initiation (Dev, Shankar, \& Qaiser, 2020). Due to these unique features, AM can be set up on a smaller scale, furthermore, it can be used locally where the consumer is, thus addressing the needs of community in an instant way (Despeisse et al., 2017), by means of designing and manufacturing tailor-made products and services delivered faster due to often shorter supply chains. It has been argued that AM can be cost-effective and could lead to creating new business opportunities, which can gain competitive advantage by retaining customers through engaging them in co-creation of personalized products and services (Turner et al., 2019). Despite the great economic and resource-efficiency potential of AM, AM and related technologies are not ubiquitously used in industry, lagging behind data analytics, cloud services and augmented reality (KPMG International \& International, 2016). In the study by KPMG on how disruptive technologies are transforming business models and the customer experience globally, AM is not among the top technologies that affects how industries develop new products and drive differentiation in monetizing products and services (KPMG International \& International, 2016); similarly in the Nordics, industries that use AM, mainly use it for creating prototypes rather than basing their business activities on AM (Dansk AM Hub, 2020). Among barriers to AM adoption by industries is the lack of knowledge about how it can support their business models and about the new opportunities it provides as well as lack of knowledge and skills regarding AM (Dansk AM Hub, 2020). Despite the barriers, it is forecasted that AM will contribute to quadrupling the economic benefits worldwide in 2024 in comparison to 2018 (Dansk AM Hub, 2020) with larger emphasis on new business models and new products.

\subsection{Circular economy as enabler of sustainability}

$\mathrm{CE}$ is seen as a radical shift in production and consumption systems with the ultimate goal of keeping value of resources in the system and eliminating waste (EMF, 2015). Moving towards $\mathrm{CE}$ involves adoption of cleaner production methods, reliance on renewable energy and digital technologies, elimination of toxic chemicals, designing durable and repairable products (European Commission, 2014). In manufacturing context, CE principles can be embedded into products, processes, internal and external operations. To assist industrial practitioners in the $\mathrm{CE}$ transition, several frameworks have been designed to i) reveal the core 'how-to' of CE, namely CE strategies such as shared product use, reduce, repurpose, reuse, remanufacture, recycle (e.g. CE Strategy scanner by Blomsma et al., 2019 or RESOLVE framework (EMF, 2015)); ii) support CE transformation of business model (Pieroni, McAloone, \& Pigosso, 2019), product development (Bocken, de Pauw, Bakker, \& van der Grinten, 2016) and value chain (Blomsma, Pigosso, \& McAloone, 2019); iii) measure inherent (i.e. resource use-oriented) CE performance (Saidani, Yannou, Leroy, \& Cluzel, 2017) or use sustainability indicators to support CE planning (Kravchenko, Pigosso, \& McAloone, 2020). While CE is seen as a pre-condition of sustainable economy, none of the CE strategies are sustainable by default and need to be monitored prior, during and after implementation to assess their contribution to sustainability (Korhonen et al., 2018). Thus, product leasing and sharing, while been seeing as strategies with greater reduction of environmental impact, may encourage higher consumption or cause 
rebound effects (Warmington-Lundström \& Laurenti, 2020), dematerialized services still require 'non-digital' inputs such as energy, water and land (Parrique, Barth, Briens, Kerschner, \& Kraus-Polk, 2019), while product life extension such as tyre retreading may negatively impact car fuel consumption due to tyre's higher rolling distance (Lonca, Muggéo, ImbeaultTétreault, Bernard, \& Margni, 2018). AM has been frequently named as a technology that could dramatically change the economy due to its potential in reducing production waste, encouraging repair and remanufacturing activities, reducing costs of inventory and obsolescence risks, thus seen as an enabler of CE towards sustainability. For sustainability consideration, any process, product or technology measurements has to account for three dimensions simultaneously, such as economic, social and environmental, to understand their sustainability potential. With this paper, we aim to understand what CE strategies can be enabled by AM and then, by utilizing a database of sustainability indicators, we point to important sustainability aspects that might be considered when planning those strategies employing AM.

\section{Methodology}

Our research approach consisted of a combination of a literature review and utilization of a database of leading sustainability performance indicators to retrieve important sustainability aspects relevant for manufacturing context. The database of indicators is available at the web$\underline{\text { address }}$ and supported by the selection procedure described in Kravchenko et al., 2020.

Main objective of the first research stage was to understand what CE strategies can be enabled by AM. Firstly, a systematic literature review was conducted by searching for a combination of key words such as circular economy, additive manufacturing and 3D printing (as these terms used interchangeably) in Scopus. The inclusion criterion for papers to be considered for data analysis and extraction was - the paper had to address proposition or practical example of AM in a CE context. Papers addressing non-industrial 3DP were also included because they could show alternative examples of AM technology application in CE context. However, papers that focused on mechanical properties of AM-related materials or experiments were excluded. Secondly, all the data was categorized according to thirteen CE strategies applicable to a manufacturing context, which were extracted from the CE strategy scanner developed earlier (Blomsma et al., 2019). A second stage of the research was focused on finding and highlighting key sustainability aspects that need to be considered when planning CE strategies enabled by AM. Sustainability aspects have been retrieved using a database of sustainability indicators for CE initiatives described in previous research by Kravchenko, Pigosso, \& McAloone, 2019. Sustainability aspects and related indicators are important to consider in the early design stage of any project or initiative to ensure a more informed decision-making if the initiative is to bring desirable sustainability benefits (Kravchenko et al., 2020).

\section{Results}

\subsection{CE strategies supported by AM}

In total, 60 papers have appeared as a result of key word search in Scopus. After applying the exclusion criteria and removing duplicates, 24 papers have been selected to understand what CE strategies can be supported by AM. Furthermore, 13 papers have been analysed using snowball technique, from which 2 papers have been selected and added to the rest, thus resulting in 26 papers satisfying the inclusion criteria.

Table 1. Number of publications according to the source and year of publication. 


\begin{tabular}{|c|c|c|}
\hline $\begin{array}{ll}\text { Source } \\
\end{array}$ & $\begin{array}{r}\text { Number of } \\
\text { publications }\end{array}$ & $\begin{array}{r}\text { Year of } \\
\text { publication }\end{array}$ \\
\hline Proceedings of the 16th Global Conference on Sustainable Manufacturing & 3 & 2019 \\
\hline Resources, Conservation and Recycling & 2 & 2020 \\
\hline Materials Today Communications & 2 & 2018 \\
\hline California Management Review & 2 & 2018 \\
\hline Journal of Cleaner Production & 2 & 2019 \\
\hline Procedia CIRP & 2 & 2018 \\
\hline Processes & 1 & 2019 \\
\hline Sustainability & 1 & 2019 \\
\hline Applied Sciences (Switzerland) & 1 & 2019 \\
\hline Additive Manufacturing & 1 & 2019 \\
\hline Journal of Manufacturing Technology Management & 1 & 2019 \\
\hline Technological Forecasting and Social Change & 1 & 2017 \\
\hline International Journal of Precision Engineering and Manufacturing & 1 & 2016 \\
\hline $\begin{array}{rr}\text { Resources } \\
\end{array}$ & 1 & 2014 \\
\hline International Journal of Production Research & 1 & 2019 \\
\hline Technology Innovation Management Review & 1 & 2015 \\
\hline Report: 3D PRINTING WITH BIOMATERIALS & 1 & 2015 \\
\hline Physics Procedia & 1 & 2016 \\
\hline Proceedings of the Summer School Francesco Turco & 1 & 2016 \\
\hline Total $=\mathbf{J}+\mathbf{C}$ & $26=18+8$ & $>2014$ \\
\hline J-journal, in bold; $C$ - conference, in italics & & \\
\hline
\end{tabular}

As seen from Table 1, the majority of papers have been published in the journals, whose focus area is either sustainability and resource efficiency (e.g. Resources, Conservation and Recycling) or technology and manufacturing advances (e.g. Journal of Production Research). 8 papers were extracted from conference proceedings, again with a clear focus of their topics on sustainability and manufacturing (e.g. Procedia CIRP). It can be noted that majority of the papers were published later than 2014, indicating growing research for CE and AM. Following Table 2, the majority of considered publications view AM as an enabler of more efficient manufacturing (11 references), with the most prominent benefits of eliminating production scrap, as material is added only where it is needed, instead of removed from where it is not (traditional manufacturing). Other benefits include elimination of excessive inventory and associated costs, and facilitation of local manufacturing (Dev et al., 2020; Machado, Winroth, \& Ribeiro da Silva, 2019). Repair and maintenance strategy is also reported as a top strategy to be enabled by AM (Ott, Pascher, \& Sihn, 2019), particularly due to AM's potential in establishing repair facilities, where broken and spare parts can be manufactured locally, thus limiting logistics costs and response time (Rahito et al., 2019). Additionally, remanufacturing strategy can also be facilitated by AM, which can directly be linked to the repair strategy with focus on spare part manufacturing to support whole product remanufacture (Lahrour \& Brissaud, 2018; Leino, Pekkarinen, \& Soukka, 2016; Saboori et al., 2019). Recycling is also a strategy frequently mentioned being supported by AM, with focus on local recycling of unmixed waste and instant use of recyclate in a 3D printer (Garmulewicz, Holweg, Veldhuis, \& Yang, 2018; Mohr \& Khan, 2015; Unruh, 2018).

Table 2. Overview of CE strategies supported by AM and benefits AM brings (numbers show number of time a specific CE strategy has been mentioned)* 


\begin{tabular}{|c|c|c|c|c|c|}
\hline CE strategies & AM enabling context & $\begin{array}{l}\text { Recur } \\
\text { rence }\end{array}$ & $\begin{array}{l}\text { Refe } \\
\text { rence }\end{array}$ & Beneficial opportunity of AM for CE & Example \\
\hline $\begin{array}{l}\text { Reinvent the } \\
\text { paradigm }\end{array}$ & $\begin{array}{l}\text { - Personalized products to build } \\
\text { customer attachment } \\
\text { - Adding functions to the product }\end{array}$ & 2 & \begin{tabular}{|r|}
6,13 \\
\end{tabular} & $\begin{array}{l}\text { - Product attachment might encourage } \\
\text { customer to keep the product for longer } \\
\text { - Multifunctionality can eliminate the need } \\
\text { for extra products }\end{array}$ & \\
\hline $\begin{array}{l}\text { Rethink \& } \\
\text { Reconfigure } \\
\text { business }\end{array}$ & $\begin{array}{l}\text { - Stimulation of new value } \\
\text { propositions (e.g. subscription } \\
\text { model to offer customized } \\
\text { products and their part } \\
\text { replacement and repair) }\end{array}$ & 3 & $4,14,17$ & $\begin{array}{l}\text { - Customization and customer co-creation } \\
\text { allows to build stronger relationship and } \\
\text { ensure customer retention and satisfaction } \\
\text { - Quicker response to customer needs }\end{array}$ & $\begin{array}{l}\text { Footware industry: 3D- } \\
\text { printed trainers } \\
\text { renewal through } \\
\text { subscription scheme }\end{array}$ \\
\hline $\begin{array}{l}\text { Reduce, } \\
\text { Restore \& } \\
\text { Avoid } \\
\text { impacts in } \\
\text { Raw material } \\
\text { and Sourcing }\end{array}$ & $\begin{array}{l}\text { - Utilization of (local) recycled } \\
\text { material as a feedstock for 3DP to } \\
\text { produce new products } \\
\text { - Monomateriality }\end{array}$ & 4 & \begin{tabular}{l|}
$, 8,10$, \\
14
\end{tabular} & $\begin{array}{l}\text { - Reduced cost of transport and material } \\
\text { procurement } \\
\text { - Reliance on local materials } \\
\text { - More control over material quality and } \\
\text { quantity (monomaterial products to ease } \\
\text { potential recycling); utilizaton of bio-based } \\
\text { materials }\end{array}$ & $\begin{array}{l}\text { 3D printed durable } \\
\text { goods (monomaterial } \\
\text { skateboard); } \\
\text { 3D printed flower pot } \\
\text { from mussel shell } \\
\text { waste }\end{array}$ \\
\hline $\begin{array}{l}\text { Reduce, } \\
\text { Restore \& } \\
\text { Avoid } \\
\text { impacts in } \\
\text { Manufacturin } \\
\mathrm{g}\end{array}$ & $\begin{array}{l}\text { - Production to order (flexible, on } \\
\text { demand, make-to-order MTO) } \\
\text { - Distributed (local) manufacturing } \\
\text { - High-precision production and no } \\
\text { additional machining tools } \\
\text { - Modularity }\end{array}$ & 11 & $\begin{array}{l}2,4,6 \\
11,12 \\
14,16 \\
20,21 \\
22,25\end{array}$ & $\begin{array}{l}\text { - Elimination of surplus attributed to } \\
\text { conventional production to stock } \\
\text { - Local manufacturing - building economy of } \\
\text { scope rather than of scale; empowerment of } \\
\text { local communities and smaller businesses } \\
\text { - Shorter supply chains and reduced costs } \\
\text { - Reduced material losses and scrap } \\
\text { - Faster 3DP machine set up and reduced } \\
\text { time response } \\
\text { - Late-stage customization to reduce excess } \\
\text { inventory }\end{array}$ & $\begin{array}{l}\text { Production of eyewear } \\
\text { (eyeglasses); 3D } \\
\text { electrode for } \\
\text { electronic industry; 3D } \\
\text { printing in metal to } \\
\text { optimize casting tools } \\
\text { in existing production } \\
\text { process }\end{array}$ \\
\hline $\begin{array}{l}\text { Reduce, } \\
\text { Restore \& } \\
\text { Avoid } \\
\text { impacts in } \\
\text { Product in } \\
\text { Use stage } \\
\end{array}$ & $\begin{array}{l}\text { - Optimization of topology } \\
\text { through complex geometries and } \\
\text { lightweight structure }\end{array}$ & 1 & 6 & $\begin{array}{l}\text { - Reduced material demand and lightweight } \\
\text { products, which in turn impact efficiency of } \\
\text { products in use }\end{array}$ & $\begin{array}{l}\text { 3D printed parts in } \\
\text { aerospace contribute } \\
\text { to lower aircraft } \\
\text { weight and lower fuel } \\
\text { use }\end{array}$ \\
\hline Upgrade & $\begin{array}{l}\text { Adding extra elements to a } \\
\text { finished product or its re-styling }\end{array}$ & 1 & 20 & $\begin{array}{l}\text { - Adding desirable features to prolong } \\
\text { product use and operation and increasing } \\
\text { customer desirability }\end{array}$ & $\begin{array}{l}\text { 3D orinted } \\
\text { ornamenents for } \\
\text { textile and furniture }\end{array}$ \\
\hline $\begin{array}{l}\text { Repair and } \\
\text { Maintenance }\end{array}$ & $\begin{array}{l}\text { Rebuilding broken parts to repair } \\
\text { products }\end{array}$ & 10 & $\begin{array}{l}3,4,5 \\
14,15 \\
16,19 \\
20,21 \\
23\end{array}$ & $\begin{array}{l}\text { - Flexible (value chain independent) } \\
\text { operation - instant production of spare } \\
\text { parts and rebuilding the broken part } \\
\text { - Reduction of packaging material and costs } \\
\text { - Proximity to the customer might encourage } \\
\text { them to repair }\end{array}$ & $\begin{array}{l}\text { Mould and die } \\
\text { repairing processes; } \\
\text { gas turbine blade } \\
\text { repair }\end{array}$ \\
\hline Re-use & & 0 & & & \\
\hline Refurbish & Refurbishing of products & 1 & 15 & - Reproduction of failed parts & $\begin{array}{l}\text { Refurbishing metallic } \\
\text { products, e.g. } \\
\text { crankshafts }\end{array}$ \\
\hline $\begin{array}{l}\text { Remanufac } \\
\text { ture }\end{array}$ & $\begin{array}{l}\text { - Remanufacture of components } \\
\text { - High-precision rebuilding and no } \\
\text { additional machining tools } \\
\text { - Reverse engineering }\end{array}$ & 7 & $\begin{array}{l}2,14 \\
15,17 \\
20,23 \\
25\end{array}$ & $\begin{array}{l}\text { - Flexible (value chain independent) } \\
\text { remanufacturing operation } \\
\text { - Reduction of packaging material and costs } \\
\text { - Reproduction of old parts }\end{array}$ & $\begin{array}{l}\text { Remanufacture of } \\
\text { structural components } \\
\text { in aerospace }\end{array}$ \\
\hline Repurpose & $\begin{array}{l}\text { Adjusting parts and printed links } \\
\text { to fit another use context }\end{array}$ & 1 & 9 & $\begin{array}{l}\text { - Prolonging use of parts in another use } \\
\text { contexts }\end{array}$ & $\begin{array}{l}\text { Linked textile sheets } \\
\text { printed in polyamide } \\
\text { that can be adjusted } \\
\text { in size and shape } \\
\end{array}$ \\
\hline Recycle & Distributed recycling of materials & 7 & $\begin{array}{l}1,14 \\
18,20 \\
21,24 \\
26\end{array}$ & $\begin{array}{l}\text { - Local (decentralized) recovery of waste } \\
\text { - Reduction of transport costs } \\
\text { - Immediate use of recycled feedstock locally } \\
\text { - More control over material quality and } \\
\text { quantity }\end{array}$ & $\begin{array}{l}\text { Recycling polymers } \\
\text { and using as a } \\
\text { feedstock for 3DP }\end{array}$ \\
\hline Recover & & 0 & & & \\
\hline
\end{tabular}

This can greatly reduce transportation costs and associated emissions and potential waste stream contamination, thus transforming current recycling system, where currently recycling 
(particularly of plastic) is not economical in the centralized context (Santander, Cruz Sanchez, Boudaoud, \& Camargo, 2020). In that matter, recycling strategy can be linked to the strategy of 'reducing impact in raw material and sourcing', where four publications present examples of how local waste, including bio-based materials, can be utilized in AM.

Furthermore, only few papers discuss such strategies as upgrade, refurbish and repurpose (Table 2). There can be several reasons for that. Firstly, upgrade and repurpose is only mentioned once, and particularly in relation to fashion and furniture industry, which could be explained by a relatively recent consideration of AM in these industries contexts (Bloomfield \& Borstrock, 2018). Refurbishment, for instance, can be often considered as either part of a repair or remanufacturing process, which can explain the limited focus in the reviewed articles. Similarly, reuse can be implicitly considered as a result of deploying other strategies, such as repair, which allows to extend the life time of a product and potentially reuse it again. Recover has not been mentioned at all, which can be explained by this strategy's focus on nutrient and energy recovery, thus limiting its applicability in AM; however it can be argued that utilizing bio-compatible materials in AM can facilitate nutrient recovery at the end of life. Interestingly, because structures with complex geometries can be 'easily' printed, there is a prominent effect on structure's weight and often on visual design, the former contributing positively to reducing impact in product use stage (e.g. reducing fuel consumption), while the latter giving the touch of 'uniqueness'. Notably, because of the potential to produce unique, customized products, several authors argue that AM can contribute to radical resource decoupling (CE strategy 'reinvent paradigm' in Table 2), where the customers would want to keep their items for longer due to the unique features embedded in them; furthermore, extra functions can be added to one product, thus reducing the need to produce several products (Minetola \& Eyers, 2018; Sauerwein, Doubrovski, Balkenende, \& Bakker, 2019).

Only few papers (3) have taken a business model (BM) perspective, investigating how AM can enable BM innovation. One example presents a case of a subscription-based BM for 3D-printed trainers, where the product is not only designed with the customer, but is designed in a modular way, to fit the subscription model, which allows the customer to replace any part of the trainers (Turner et al., 2019). Authors argue that the BM can be supported by AM because of its ability to enable personalization and quick response to customer needs. Furthermore, because or relatively affordable equipment and material (in this case polymers), AM can stimulate development of new value propositions and give access to the market of new enterprises (Despeisse et al., 2017), which can boost the local economy, also of developing countries, where some local materials can be used in 3D printers (example of mussel shells by (Sauerwein \& Doubrovski, 2018)). These publications provide practical examples of how AM can fully unlock the potential of $\mathrm{CE}$, starting with $\mathrm{BM}$ reconfigurations, product development and the service package, all allowing to deploy several CE strategies in conjunction.

\section{Discussion}

\subsection{Sustainability aspects for AM-enabled CE strategies focusing on products}

After having an overview of the CE strategies enabled by AM, it becomes evident that some strategies have already been enabled by AM to a larger extent, namely original manufacturing, repair and maintenance and remanufacturing. Because of the nature of these operations, it can be argued that they can be labour and resource intensive. Using the database of indicators and corresponding selection procedure, these strategies can be measured by the largest number of indicators covering environmental, economic and social aspects. Furthermore, performance indicators applicable to manufacturing are often applicable to repair, refurbishment and 
remanufacturing, with indicators 'energy use for a process' and 'wastewater generation' as examples. This can be explained by the nature of $\mathrm{CE}$ strategies, i.e. repair and remanufacture often require production and supply of spare parts, disassembly, cleaning, repair and reassembly, thus requiring substantial resource and labour input and costs. The core of those strategies is to add or restore value of a product (Blomsma et al., 2019). In summary, repair and remanufacturing operations become a 'production' process for a repairable and remanufacturable product. To present sustainability aspects that might be important to consider when planning for manufacturing, repair, refurbishment and remanufacturing activities using $\mathrm{AM}$, we combine these strategies under one group - product value adding processes. Then we use the database of leading performance indicators introduced in Methodology and select these strategies to reveal key sustainability aspects. We then provide argumentations of why these aspects and related indicators are important to be measured during AM planning.

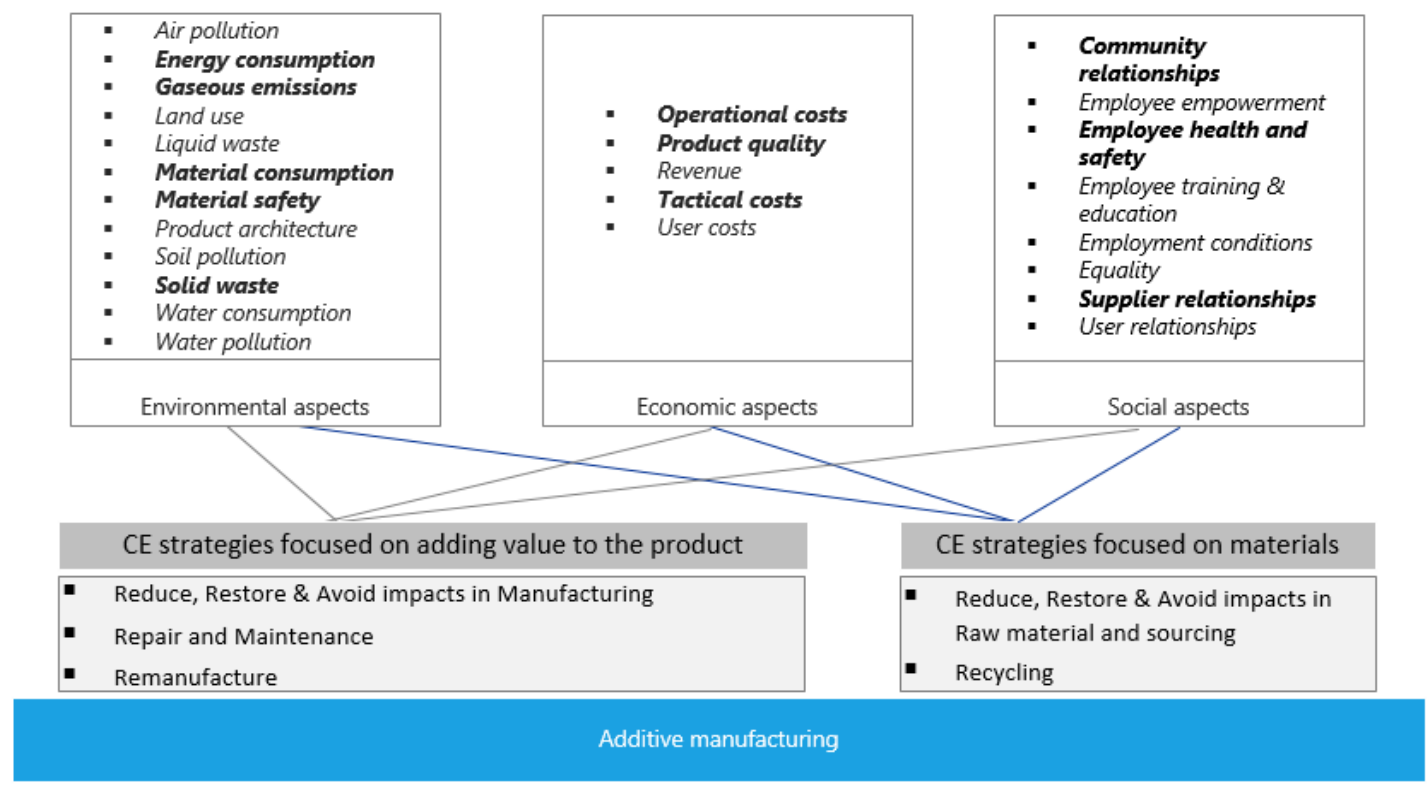

Figure 1. List of economic, environmental and social aspects important for CE strategies focused on adding value to the product (all aspects), and CE strategies focused on materials (aspects marked in bold), with additive manufacturing as their enabler.

As seen from the Fig. 1, there are multiple sustainability aspects that might be useful to measure to understand the potential sustainability performance of CE strategies supported by AM. As presented earlier, regardless of what CE strategy AM is enabling, operation of AM-related equipment, e.g. 3DP machine, requires energy inputs, which makes it one of the most significant aspects to consider and measure. Electric energy is required to operate the machine and run cooling fans, often needed to cool down a heating element used to melt the material (e.g. some plastic requires heating up to $200^{\circ} \mathrm{C}$ ) (Kreiger \& Pearce, 2013; van Wijk \& van Wijk, 2015). While arguments are provided that AM might be less energy intensive in comparison to conventional manufacturing (Kreiger \& Pearce, 2013), a case by case analysis has to be done. Thus, Minetola \& Eyers, 2018 report increase in costs and energy use when manufacturing a mobile phone case with PLA and ABS and comparing it with injection molding; similarly, Fredriksson, 2019 compared production of a metal detail by AM and traditional manufacturing, reporting an increase of energy use and related $\mathrm{CO}_{2}$ emissions for $\mathrm{AM}$ case. Furthermore, some indicators from the database suggest measuring energy losses, which is important considering heat release from AM equipment. Therefore, energy use, energy loss and associated emissions (e.g. energy source at the facility) and costs are significant aspects to be measured for any type of AM process for any type of material input. Regarding other inputs, water and other resources (e.g. gases as argon) need to be added into sustainability considerations. While some industries 
are known for their large water footprint (e.g. textile), water intensity of some industrial processes, including AM processes, has received little attention. According to Kellens et al., 2017, 155 litres of water is used for the process of metallic glass atomization, just for $1 \mathrm{~kg}$ of metallic glass powder. We address other material requirements, mainly used for feedstock for $\mathrm{AM}$, later when discussing raw materials and recycling strategies.

Another important aspect is waste. Abounding sources suggest a considerable benefit of AM in reducing waste, which is generated as scrap in conventional (manufacturing) process. Because of an inherent material 'add-on' instead of 'cut out', AM minimizes amount of scrap (Kellens et al., 2017). However, pre-manufacturing, manufacturing and post-manufacturing stages should be considered (Matsumoto et al., 2016). Specially in post-manufacturing, there is often a need to smoothen rough surface, which results in generating material scrap (metal polishing), waste and requires additional tooling and inputs (acetone for plastic smoothing), thus adding costs, however these aspects are being largely underestimated (Kellens et al., 2017). This also brings a discussion about health and safety issues. Small particles from polishing process might contribute to air pollution and affect workplace safety (e.g. for 3D machine operator). Workplace safety (social dimension aspects) require special attention for most of AM processes. Some powder-based processes require handling powder composed of various metals (titanium, nickel, cobalt, chromium, etc.), some of which are dangerous at high temperatures and hazardous to human health and environment, causing allergic skin reaction, genetic defects or damage to aquatic life (Arrizubieta et al., 2020). These aspects require an AM operating facility to control liquid and hazardous waste, and monitor soil and water pollution (Fig. 1, environmental aspects). Because of the specifics of the AM process, employee would require training and education (Fig. 1, social aspects). Economic factors are also important to measure. Costs associated with material and other inputs, running machines, post processing operations and forward and reverse supply chain need to be considered.

\subsection{Sustainability aspects for AM-enabled CE strategies focusing on materials}

Material selection and sourcing are critical stages to ensure a more informed and sustainable procurement process, influencing the quality and sustainability performance of operational processes and final products. A CE strategy 'reduce, restore and avoid impacts in raw material and sourcing" has focus on sourcing of materials, suitable for a CE system. Such materials include recyclable, recycled, biodegradable and renewable. Material selection and sourcing are relevant not only for original manufacturing, but also for repair and maintenance, refurbishment, remanufacture, as new material and other inputs need to be supplied in order to restore the value of a product. Some of the significant sustainability aspects relate to energy and resource consumption of feedstock materials (called material embodied energy, material embodied water, etc.), their safety (e.g. toxicity), costs, as well as supplier and sourcing origin (Fig. 1, coloured in bold to distinguish from other, less significant aspects). Four publications put emphasis on using recycled materials in 3DP as their main feedstock. Particularly, certain types of plastic have gained big popularity in AM, such as ABS, PP, PLA. While fossil virgin plastic still dominate in AM (e.g. 3D printed nylon textile), bio-based and recycled plastics are gaining attention. In terms of recycled plastics, their applicability is limited in AM due to the losses of some mechanical properties as a result of recycling process; furthermore, some reinforcements of carbon or glass fibre might to be added to the recycled plastic for their durability, which questions the material/product suitability for recycling at the end of its life (Byard et al., 2019). Therefore, the database of sustainability indicators can help retrieving the relevant set of indicators to measure performance on some critical sustainability aspects when it comes to material selection (Fig. 1, environmental aspects in bold). 
Additionally, it is important to understand whether any plastics contain contaminants (material safety aspect), such as flame retardants, to avoid contaminating plastics flows in case the material is to be destined for open loop recycling. Similar thinking is applicable to bio-based plastics, which does not necessarily mean they are 'better' and biodegradable by default. Biobased PE and PLA can be both made of bio material (e.g. sugar cane), however only PLA is biodegradable (ensuring a controlled process). These aspects require understanding of not only environmental performance (e.g. biodegradability) of these plastic types, but also their origin and renewability, which can greatly affect social aspects. One example of bio-based, local, recyclable and bio-compatible material is given by Sauerwein \& Doubrovski, 2018, who investigated use of mussel shell (organic waste) and its powder in 3DP. Similar critical aspects are relevant for metals used as inputs in 3DP. As mentioned earlier, some of the widely used metals in AM are metals and alloys with superior properties as oxidation and high stress resistance, which makes those materials costly and desired by particular industries. When it comes to metals and minerals, it is important to understand the social aspects (Fig. 1, social aspects in bold) of supply chain as some of the minerals can be sourced from conflict zones or areas with poor working conditions (e.g. cobalt and gold mining). 'Responsible supply' is key towards ensuring socially sustainable sourcing, also for processes utilizing AM. Social risks can be also associated with secondary supplies, such as recycled metals, where metal recyclers might need to demonstrate environmentally sound recycling process and document fair work conditions, which is not always the case when it comes to e-waste (containing gold and copper) recycling practices in unauthorized facilities or in developing countries (Giurco et al., 2014).

Majority of papers mentioning recycling strategy see AM as an alternative, often cheaper and more efficient, way to process waste and use it as a feedstock for a 3DP process. One of the main advantages AM can bring is to encourage local recycling of particular waste streams, such as plastic, where a plastic filament is created with a help of a recycling bot, joined with a 3DP machine that can utilize the filament directly (Zhong \& Pearce, 2018). In addition to mechanical properties of recycled materials, multiple sustainability aspects need to be considered when attempting to recycle materials and waste, including waste generation from 3DP process itself. Energy and water use, solid, liquid and hazardous waste, costs and 3DP operator's safety (e.g. metal powder recycling) are among important aspects to be measured.

\subsection{Sustainability aspects for AM-enabled business model and product development}

In order to enable multiple $\mathrm{CE}$ strategies, rethinking $\mathrm{BM}$ and product development (PD) is essential. $\mathrm{BM}$ for $\mathrm{CE}$ often requires altering value capture and delivery mode, e.g. through subscription and service offerings, as well as value creation mechanisms, e.g. take back scheme (de Padua Pieroni, McAloone, \& Pigosso, 2019). Furthermore, PD is as essential because it allows to effectively operationalise a particular CE-oriented BM, i.e. designing a product to be repairable if the service provision is envisaged (Bocken et al., 2016). The opportunities AM brings for new BM is product and service customization, which allows to build stronger relationship with the customers and ensure their retention and satisfaction; furthermore, AM allows business respond quicker to customer needs, e.g. by producing a spare part to replace a broken one or upgrade product look or function. Similarly, sustainability aspects concerning the rate of product (part) replacement, associated resource consumption and costs need to be considered by a business. One of the challenges of such promptness is to control the rate of product returns and upgrades as it may induce more resource consumption, for instance, because of a subscription model a customer may want to upgrade a product's part more often when needed (Minetola \& Eyers, 2018). Similar 'warnings' exist for private 3D printers, where access to relatively cheap materials allows users to print excess products. Complexity of CE often requires simultaneous redesign of BM, products, operations, service delivery and value 
chains, therefore, it is crucial to understand what business processes and CE strategies are involved in CE implementation, consequently selecting the most relevant sustainability aspects and indicators to support more sustainable CE transition (Kravchenko et al., 2020).

\section{Conclusion}

AM is a promising technology that could radically change the manufacturing landscape, add value to original manufacturing activities, add-on services and drive business model and product innovation. AM is also one of the building blocks of Industry 4.0, which are both seen as powerful enablers of $\mathrm{CE}$, aiming at promoting business growth without increase in resource consumption. This paper has explored the extant literature to understand what particular $\mathrm{CE}$ strategies can be enabled by AM. Our findings reveal that AM is often suggested for original equipment manufacturing, repair and maintenance and remanufacturing activities. Furthermore, AM supports CE strategies focused on materials as AM technology could positively contribute to local recycling and production of recycled materials. In addition, several articles provide examples of new business models and products designs supported by AM, which is an emerging topic. Consequently, it may be expected that more research and practical examples will be appearing on the link between AM and novel BM, products and services. It is, therefore, crucial to ensure any of these initiatives are supported by measurements to ensure a sustainabilityoriented CE transformation enabled by AM. We have thus provided examples of critical sustainability aspects that need to be taken into account in early stages of AM-enabled CE design. Following examples provided earlier, there are no sustainably superior cases of either CE or AM technology, which calls for more case by case analysis. In this context, the sustainability indicator database used in this work could provide a systematic way of identifying key sustainability aspects relevant for a specific CE strategy enabled by AM. This techniques could support not only comparison of AM and traditional operations, but point out at improvement opportunities within AM. Taking into account sustainability aspects and understanding potential sustainability performance of products, processes and technologies is a cornerstone of implementing more sustainable solutions.

Appendix: References in Table 1 are numbered as follows (full references are provided in References chapter): 1- Santander, Cruz Sanchez, Boudaoud, \& Camargo, 2020; 2- Dev et al., 2020; 3- Rahito et al., 2019; 4- Turner et al., 2019; 5- Saboori et al., 2019; 6- Sauerwein, Doubrovski, Balkenende, \& Bakker, 2019; 7- Byard et al., 2019; 8- Nascimento et al., 2019; 9- Bloomfield \& Borstrock, 2018; 10- Sauerwein \& Doubrovski, 2018; 11- Unruh, 2018; 12- Garmulewicz, Holweg, Veldhuis, \& Yang, 2018; 13- Minetola \& Eyers, 2018; 14- Despeisse et al., 2017; 15- Leino, Pekkarinen, \& Soukka, 2016; 16- Angioletti et al., 2016; 17- Matsumoto et al., 2016; 18- Giurco, Littleboy, Boyle, Fyfe, \& White, 2014; 19- Zhong \& Pearce, 2018; 20- Ott, Pascher, \& Sihn, 2019; 21- Fredriksson, 2019; 22- van Wijk \& van Wijk, 2015; 23Lahrour \& Brissaud, 2018; 24- Peeters, Kiratli, \& Semeijn, 2019; 25- Machado et al., 2019; 26- Mohr \& Khan, 2015.

\section{Acknowledgement}

This article is one of the outcomes of the research project CIRCit, funded by the Nordic Green Growth Research and Innovation Programme with grant number 83144.

\section{References}

Angioletti, C. M., Sisca, F. G., Luglietti, R., Taisch, M., \& Rocca, R. (2016). Additive Manufacturing as an opportunity for supporting sustainability through implementation of circular economies. Proc. of the Summer School Francesco Turco, 13-15-Sept, 25-30.

Antikainen, M., Uusitalo, T., \& Kivikytö-Reponen, P. (2018). Digitalisation as an Enabler of Circular Economy. Procedia CIRP, 73, 45-49. https://doi.org/10.1016/j.procir.2018.04.027

Arrizubieta, J. I., Ukar, O., Ostolaza, M., \& Mugica, A. (2020). Study of the Environmental 
Implications of Using Metal Powder in Additive Manufacturing and Its Handling. Metals, 10, 261, 25. https://doi.org/doi:10.3390/met10020261

Blomsma, F., Pieroni, M., Kravchenko, M., Pigosso, D., Hildenbrand, J., Kristinsdottir, A. R., ... McAloone, T. (2019). Developing a circular strategies framework for manufacturing companies to support circular economy oriented innovation. Journal of Cleaner Production, 241. https://doi.org/https://doi.org/10.1016/j.jclepro.2019.118271

Blomsma, F., Pigosso, D. C., \& McAloone, T. C. (2019). A Theoretical Foundation for Developing a Prescriptive Method for the Co-Design of Circular Economy Value Chains. Proceedings of the Design Society: International Conference on Engineering Design, 1(1), 3141-3150. https://doi.org/10.1017/dsi.2019.321

Bloomfield, M., \& Borstrock, S. (2018). Modeclix. The additively manufactured adaptable textile. Materials Today Communications, 16(May), 212-216. https://doi.org/10.1016/j.mtcomm.2018.04.002

Bocken, N. M. P., de Pauw, I., Bakker, C., \& van der Grinten, B. (2016). Product design and business model strategies for a circular economy. Journal of Industrial and Production Engineering, 33(5), 308-320. https://doi.org/10.1080/21681015.2016.1172124

Byard, D. J., Woern, A. L., Oakley, R. B., Fiedler, M. J., Snabes, S. L., \& Pearce, J. M. (2019). Green fab lab applications of large-area waste polymer-based additive manufacturing. Additive Manufacturing, 27(September 2018), 515-525. https://doi.org/10.1016/j.addma.2019.03.006

Dansk AM Hub. (2020). Tendenser, muligheder og barrierer i AM landskabet.

de Padua Pieroni, M., McAloone, T., \& Pigosso, D. (2019). Business Model Innovation for Circular Economy: Integrating Literature and Practice into a Conceptual Process Model. Proceedings of the Design Society: International Conference on Engineering Design, 1(1), 2517-2526. https://doi.org/10.1017/dsi.2019.258

Despeisse, M., Baumers, M., Brown, P., Charnley, F., Ford, S. J., Garmulewicz, A., ... Rowley, J. (2017). Unlocking value for a circular economy through 3D printing: A research agenda. Technological Forecasting and Social Change, 115, 75-84. https://doi.org/10.1016/j.techfore.2016.09.021

Dev, N. K., Shankar, R., \& Qaiser, F. H. (2020). Industry 4.0 and circular economy: Operational excellence for sustainable reverse supply chain performance. Resources, Conservation and $\begin{array}{lll}\text { Recycling, } & 104583 .\end{array}$ https://doi.org/10.1016/j.resconrec.2019.104583

EC. (2019). Internal Market, Industry, Entrepreneurship and SMEs. Retrieved November 11, 2019, https://ec.europa.eu/growth/smes/business-friendly-environment/sme-definition_en

EMF. (2015). Circularity Indicators: An Approach to Measuring Circularity. Ellen MacArthur Foundation, 12. https://doi.org/10.1016/j.giq.2006.04.004

European Commission. (2014). Scoping study to identify potential circular economy actions, priority sectors, material flows and value chains - Environment policy and protection of the environment - EU Bookshop. Report. https://doi.org/10.2779/29525

Fredriksson, C. (2019). Sustainability of metal powder additive manufacturing. Procedia Manufacturing, 33, 139-144. https://doi.org/10.1016/j.promfg.2019.04.018

Garmulewicz, A., Holweg, M., Veldhuis, H., \& Yang, A. (2018). Disruptive Technology as an Enabler of the Circular Economy: What Potential Does 3D Printing Hold? California Management Review, 60(3), 112-132. https://doi.org/10.1177/0008125617752695

Giurco, D., Littleboy, A., Boyle, T., Fyfe, J., \& White, S. (2014). Circular economy: Questions for responsible minerals, additive manufacturing and recycling of metals. Resources, 3(2), 432-453. https://doi.org/10.3390/resources3020432

Kellens, K., Baumers, M., Gutowski, T. G., Flanagan, W., Lifset, R., \& Duflou, J. R. (2017). Environmental Dimensions of Additive Manufacturing: Mapping Application Domains 
and Their Environmental Implications. Journal of Industrial Ecology, 21, S49-S68. https://doi.org/10.1111/jiec.12629

Korhonen, J., Honkasalo, A., \& Seppälä, J. (2018). Circular Economy: The Concept and its Limitations. Ecological Economics, 143, 37-46. https://doi.org/10.1016/j.ecolecon.2017.06.041

KPMG International, \& International, K. (2016). The disruptors are the disrupted. KPMG International, 32. https://doi.org/10.1126/science.1151810

Kravchenko, M., Pigosso, D. C. A., \& McAloone, T. C. (2019). Towards the ex-ante sustainability screening of Circular Economy initiatives in manufacturing companies : consolidation of leading sustainability-related performance indicators. Journal of Cleaner Production, 118318. https://doi.org/10.1016/j.jclepro.2019.118318

Kravchenko, M., Pigosso, D. C. A., \& McAloone, T. C. (2020). A Procedure to Support Systematic Selection of Leading indicators for Sustainability Performance Measurement of Circular Economy Initiatives. Sustainability (Switzerland), 12(3), 21. https://doi.org/10.3390/su12030951

Kreiger, M., \& Pearce, J. M. (2013). Environmental life cycle analysis of distributed threedimensional printing and conventional manufacturing of polymer products. ACS Sustainable Chemistry and Engineering, 1(12), 1511-1519. https://doi.org/10.1021/sc400093k

Lahrour, Y., \& Brissaud, D. (2018). A Technical Assessment of Product/Component Remanufacturability for Additive Remanufacturing. Procedia CIRP, 69(May), 142-147. https://doi.org/10.1016/j.procir.2017.11.105

Leino, M., Pekkarinen, J., \& Soukka, R. (2016). The role of laser additive manufacturing methods of metals in repair, refurbishment and remanufacturing - Enabling circular economy. Physics Procedia, 83, 752-760. https://doi.org/10.1016/j.phpro.2016.08.077

Lonca, G., Muggéo, R., Imbeault-Tétreault, H., Bernard, S., \& Margni, M. (2018). Does material circularity rhyme with environmental efficiency? Case studies on used tires. Journal of Cleaner Production, 183, 424-435. https://doi.org/10.1016/j.jclepro.2018.02.108

Machado, C. G., Winroth, M. P., \& Ribeiro da Silva, E. H. D. (2019). Sustainable manufacturing in Industry 4.0: an emerging research agenda. International Journal of Production Research, 7543. https://doi.org/10.1080/00207543.2019.1652777

Matsumoto, M., Yang, S., Martinsen, K., \& Kainuma, Y. (2016). Trends and research challenges in remanufacturing. International Journal of Precision Engineering and Manufacturing - Green Technology, 3(1), 129-142. https://doi.org/10.1007/s40684-0160016-4

Minetola, P., \& Eyers, D. (2018). Energy and Cost Assessment of 3D Printed Mobile Case Covers. Procedia CIRP, 69(May), 130-135. https://doi.org/10.1016/j.procir.2017.11.065

Mohr, S., \& Khan, O. (2015). Editorial: 100th Issue. Technology Innovation Management Review, 5(11), 20-25. Retrieved from www.timreview.ca

Nascimento, D. L. M., Alencastro, V., Quelhas, O. L. G., Caiado, R. G. G., Garza-Reyes, J. A., Lona, L. R., \& Tortorella, G. (2019). Exploring Industry 4.0 technologies to enable circular economy practices in a manufacturing context: A business model proposal. Journal of Manufacturing Technology Management, 30(3), 607-627. https://doi.org/10.1108/JMTM-03-2018-0071

Ogden, R. (2018). Reinventing business through disruptive technologies - Sector trends and investment opportunities for firms in emerging markets. Retrieved from www.ifc.org

Ott, K., Pascher, H., \& Sihn, W. (2019). Improving sustainability and cost efficiency for spare part allocation strategies by utilisation of additive manufacturing technologies. Procedia Manufacturing, 33, 123-130. https://doi.org/10.1016/j.promfg.2019.05.001 
Parrique, T., Barth, J., Briens, F., Kerschner, C., \& Kraus-Polk, A. (2019). Decoupling debunked. Evidence and arguments against green growth as a sole strategy for sustainability. Retrieved from eeb.org/decoupling-debunked

Peeters, B., Kiratli, N., \& Semeijn, J. (2019). A barrier analysis for distributed recycling of 3D printing waste: Taking the maker movement perspective. Journal of Cleaner Production, 241, 118313. https://doi.org/10.1016/j.jclepro.2019.118313

Pieroni, M. P. P., McAloone, T. C., \& Pigosso, D. C. A. (2019). Business model innovation for circular economy and sustainability: A review of approaches. Journal of Cleaner Production, 215, 198-216. https://doi.org/10.1016/j.jclepro.2019.01.036

Rahito, Wahab, D. A., \& Azman, A. H. (2019). Additive manufacturing for repair and restoration in remanufacturing: An overview from object design and systems perspectives. Processes, 7(11). https://doi.org/10.3390/pr7110802

Saboori, A., Aversa, A., Marchese, G., Biamino, S., Lombardi, M., \& Fino, P. (2019). Application of directed energy deposition-based additive manufacturing in repair. Applied Sciences (Switzerland), 9(16). https://doi.org/10.3390/app9163316

Saidani, M., Yannou, B., Leroy, Y., \& Cluzel, F. (2017). How to Assess Product Performance in the Circular Economy? Proposed Requirements for the Design of a Circularity Measurement Framework. Recycling, 2(1), 6. https://doi.org/10.3390/recycling2010006

Santander, P., Cruz Sanchez, F. A., Boudaoud, H., \& Camargo, M. (2020). Closed loop supply chain network for local and distributed plastic recycling for 3D printing: a MILP-based optimization approach. Resources, Conservation and Recycling, 154(September 2019), 104531. https://doi.org/10.1016/j.resconrec.2019.104531

Sauerwein, M., \& Doubrovski, E. L. (2018). Local and recyclable materials for additive manufacturing: 3D printing with mussel shells. Materials Today Communications, 15(June 2017), 214-217. https://doi.org/10.1016/j.mtcomm.2018.02.028

Sauerwein, Marita, Doubrovski, E., Balkenende, R., \& Bakker, C. (2019). Exploring the potential of additive manufacturing for product design in a circular economy. Journal of Cleaner Production, 226, 1138-1149. https://doi.org/10.1016/j.jclepro.2019.04.108

Shahrubudin, N., Lee, T. C., \& Ramlan, R. (2019). An overview on 3D printing technology: Technological, materials, and applications. Procedia Manufacturing, 35, 1286-1296. https://doi.org/10.1016/j.promfg.2019.06.089

Turner, C., Moreno, M., Mondini, L., Salonitis, K., Charnley, F., Tiwari, A., \& Hutabarat, W. (2019). Sustainable production in a circular economy: A business model for re-distributed manufacturing. $\quad$ Sustainability $\quad$ (Switzerland), 11(16), 1-19. https://doi.org/10.3390/su11164291

Unruh, G. (2018). Circular Economy, 3D Printing, and the Biosphere Rules. California Management Review, 60(3), 95-111. https://doi.org/10.1177/0008125618759684

van Wijk, A., \& van Wijk, I. (2015). 3D printing with biomaterials: Towards a sustainable and circular economy. 3D Printing with Biomaterials: Towards a Sustainable and Circular Economy. https://doi.org/10.3233/978-1-61499-486-2-i

Warmington-Lundström, J., \& Laurenti, R. (2020). Reviewing circular economy rebound effects: The case of online peer-to-peer boat sharing. Resources, Conservation and Recycling: X, 5(July 2019), 100028. https://doi.org/10.1016/j.rcrx.2019.100028

Zhong, S., \& Pearce, J. M. (2018). Tightening the loop on the circular economy: Coupled distributed recycling and manufacturing with recyclebot and RepRap 3-D printing. Resources, Conservation and Recycling, 128(July 2017), 48-58. https://doi.org/10.1016/j.resconrec.2017.09.023 